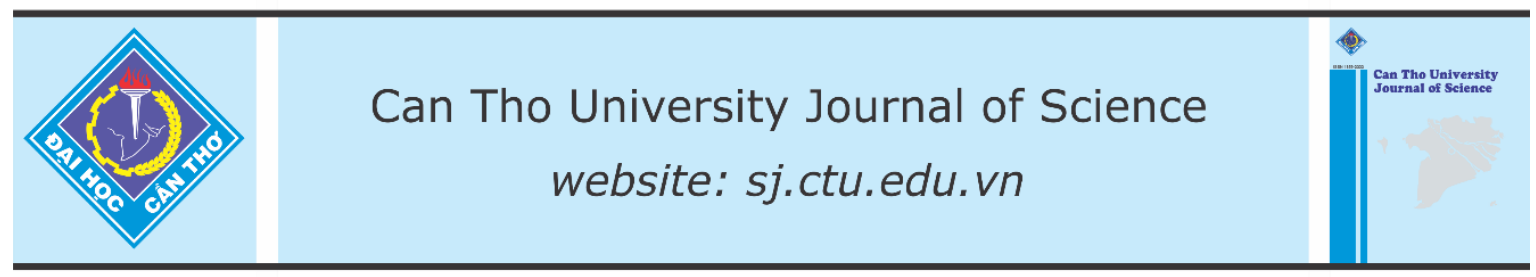

DOI: 10.22144/ctu.jen.2021.028

\title{
The effect of heating factors on the properties of heat-induced surimi gel under ohmic heating
}

\author{
Nguyen Thi $\operatorname{Van}^{1 *}$, Nguyen Hong Ngan ${ }^{1}$ and Emiko Okazaki ${ }^{2}$ \\ ${ }^{1}$ Food Science and Technology Faculty, Nha Trang University, Viet Nam \\ ${ }^{2}$ Food Processing Laboratory, Tokyo University of Marine Science and Technology, Japan \\ *Correspondence: Nguyen Thi Van (email: vannt@ntu.edu.vn)
}

\section{Article info.}

Received 18 Feb 2021

Revised 03 Jul 2021

Accepted 31 Jul 2021

\section{Keywords}

Electrical conductivity, heating rate, ohmic heating, physical properties, surimi gel

\begin{abstract}
Ohmic heating $(\mathrm{OH})$ is a method that heat is generated within the food due to its electrical resistance, resulting in a relatively linear heating rate and uniform temperature distribution. Because surimi-based paste contains water and salts, the conductivity is sufficiently good for the ohmic effect. Gelation induced by $\mathrm{OH}$ greatly depends on heating conditions such as heating speed, heating time or electrical conductivity. However, the detailed information obtained is quite limited. Therefore, in order to clarify how ohmic heating affects the physical properties of surimi gel under $\mathrm{OH}$, gels from croaker surimi (SA grade) were obtained using different heating conditions (heating rate, heating time, or salt concentration - electrical conductivity). Furthermore, the gels heated by ohmic heating were compared with the gel obtained by conventional water-bath heating. The results showed that, at the same heating rates, higher salt concentration generated better surimi gels for croaker surimi. Gels cooked ohmically at a slow heating rate performed significantly better than those cooked at a fast heating rate or heated conventionally in a water bath. There was little discernible difference in protein pattern between gels heated by $\mathrm{OH}$ and conventional water bath heating at fast heating rates with two different salt concentrations. The results also indicated that holding time at target temperature showed no effect on the gel. These results suggested that the properties of heat-induced surimi gels by $\mathrm{OH}$ were affected by not only heating speed but also holding time at maximum temperature and salt content.
\end{abstract}

\section{INTRODUCTION}

Ohmic heating, also referred to Joule heating, electrical resistance heating or electroconductive heating, is defined as a process in which the material to be heated (for example a reaction mixture), which behaves as an electrical ohmic heater, is heated by passing an AC electrical current through it (Shiba, 1992). The heat is generated in situ and dissipated directly in the medium with very high efficiency
(>90\%) by Joule effect, eliminating the heat-transfer step from the surroundings to the medium by means of temperature gradients or hot surfaces (hot plate, heat mantle) (Vicente et al., 2006). As a result, a fast and uniform heating (temperature homogeneity) is achieved and the fluctuation of the applied electric field in the reactor increases the directional dynamics of charged species and dipole orientation in solution. 
Ohmic heating has attracted considerable attention in the last two decades for the thermal processing of foods due to its rapid and uniform treatment coupled with its high-energy efficiency and technical simplicity. Ohmic heating has been used for many food processes such as pasteurization, dehydration, extraction, microbial inactivation, blanching, and thawing (de Alwis et al., 1990; Varghese et al., 2014). The heating rate is known to have a significant effect on the gelation of muscle protein (Tapitchayangkoon et al., 2012). Gelation induced by ohmic heating greatly depends on heating conditions, including voltage gradient, heating time, or electrical conductivity (EC).

In the case of ohmic heating, it is possible to heat to the desired temperature in a short time, but unknown whether the time is enough or not to complete the gelation of surimi. Therefore, the study of holding time - the time that holds samples at the final temperature, on the gelation of surimi, is necessary. Besides, in ohmic heating, the EC of foodstuffs is profoundly affected by food ingredients, such as salts and acids. It is reported that the EC had a direct relationship with the level of salt concentration. As the concentration of salt increased, the EC values also increased along with temperature rise and the resulting heating rates. During the manufacturing of surimi-based products, salt is required to extract myofibrillar proteins and consequently develop the desired texture upon cooking. Salt also lowers water activity, and therefore, suppresses the growth of foodborne pathogens. Also, recently, consumers are demanding healthier foods, and there is great interest in light-salt products from manufacturers. According to Standard Tables of Food Composition in Japan (Resources Council Report, 2000), there are a variety of surimi-based products containing low salt content. For example, salt content in datemaki, tsumire, and hanpen is $0.9,1.4$, and $1.5 \%$, respectively, whereas yaki-chikuwa $2.1 \%$, crab stick analog $2.2 \%$, and steamed kamaboko $2.5 \%$. Hence, it is needed to clarify the effect of salt content on the heating conditions by ohmic heating for surimi.

Therefore, this study is aimed to determine the effect of heating rates, holding time, and sodium chloride on the physical properties of croaker surimi gels.

\section{MATERIALS AND METHODS}

\subsection{Materials}

Croaker (Theragra chalcogramma) surimi (SA grade) was produced by Pacific Seafoods Corp., Portland, OR. The surimi was cut into small blocks (about $500 \mathrm{~g}$ ), vacuum packed, and stored at $-30^{\circ} \mathrm{C}$ during the experiments. Reagents used for gel electrophoresis were obtained from Bio-Rad (Hercules, Calif., USA.). All other chemicals were of analytical grade.

\subsection{Ohmic heating apparatus}

The ohmic heating device was shown in Fig. 1. The device consisting of an ohmic heating machine was produced by Frontier Engineering Co. Ltd. This machine provides electricity to heat the sample. Desired voltages, final temperature, or holding heating time can be adjusted. Electricity current output from the ohmic heating machine was connected with the electrodes that attach with a chamber. A wooden holding sample chamber (height, $30 \mathrm{~cm}$; width, 12 $\mathrm{cm}$; depth is adjustable with a stainless-steel electrode at each end; the size of the electrode is $10 \times 10$ $(\mathrm{cm})$. The distance between the two electrodes was adjustable. Sample (surimi paste) was stuffed in plastic tubes (diameter, $2.5 \mathrm{~cm}$; length, $2.5 \mathrm{~cm}$ ) and placed between the electrodes. The applied voltage was adjusted concerning to the salt concentration of samples to achieve a constant electric field strength. 


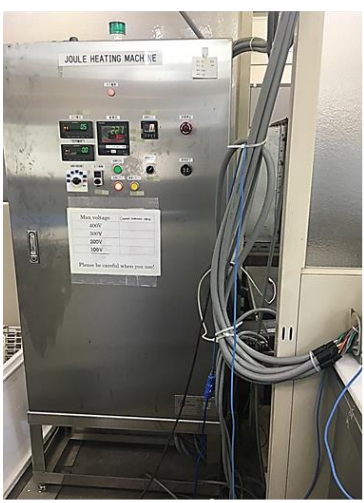

(a)

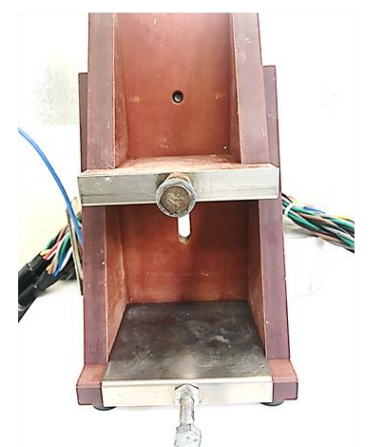

(b)

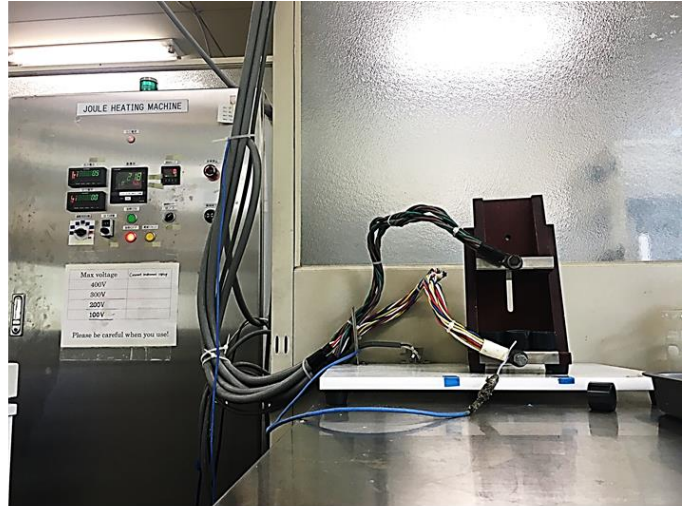

(c)

Fig. 1. Ohmic heating devices: (a) ohmic heating machine, (b) the chamber that holding samples (includes electrodes), (c) apparatus of ohmic heating system

\subsection{Surimi paste preparation}

To prepare the pastes, frozen surimi was thawed at $3^{\circ} \mathrm{C}$ overnight before being cut into small cubes (1$1.5 \mathrm{~cm}^{3}$ ). Surimi cubes were chopped at $1,500 \mathrm{rpm}$ for 1.5 min under vacuum of 0.9 bar, using a vacuum cutter (UMC-5, Stephan Machinery Corp, Hameln, Germany) equipped with a chilling system. Sodium chloride $(1.5 \%$ or $2.5 \% \mathrm{w} / \mathrm{w})$ was added, and this mixture was chopped for $1.5 \mathrm{~min}$ at $1,500 \mathrm{rpm}$; then, cold water $\left(1-2^{\circ} \mathrm{C}\right)$ was added to a moisture content of $80.0 \%$, and the mixture was chopped continuously at $1,500 \mathrm{rpm}$ for $5 \mathrm{~min}$ while maintaining a temperature below $10^{\circ} \mathrm{C}$ (Tuankriangkrai \& Benjakul, 2010). The surimi paste was prepared under vacuum to prevent the inclusion of air bubbles, and then covered in ice to maintain the temperature at about $1-4^{\circ} \mathrm{C}$ until gel preparation.

\subsection{Surimi gel preparation}

The surimi paste was extruded into the plastic tubes (inside diameter $2.5 \mathrm{~cm}$, length: $2.5 \mathrm{~cm}$, thickness of the tube: $0.2 \mathrm{~cm}$ ), and then heated by three different heating treatments (Fig. 2):

a) Heated in a water bath at $90^{\circ} \mathrm{C}$ for $30 \mathrm{~min}$. For this heating treatment, surimi paste was stuffed into the plastic casing tubes (diameter, $2.5 \mathrm{~cm}$; length, $2.5 \mathrm{~cm}$ ) and placed in a plastic bag. Then, surimi paste was heated in a water bath (WB) at $90^{\circ} \mathrm{C}$ for $30 \mathrm{~min}$.

b) Heated ohmically at different heating rates $\left(10,40\right.$, and $\left.80^{\circ} \mathrm{C} / \mathrm{min}\right)$ to $90^{\circ} \mathrm{C}$ and kept at $90^{\circ} \mathrm{C}$ for 0 and $120 \mathrm{sec}$, using an ohmic heating machine (Frontier Engineering, Co., Ltd., Tokyo, Japan), 9 samples were placed between two movable electrodes attached to the holding chamber, and then the upper electrode was pressed down to form a tight attachment to both sides of the tubes in order to secure a sample length of $2.5 \mathrm{~cm}$.

c) Heated ohmically at different heating rates (3, $5,10,40,80$ and $120^{\circ} \mathrm{C} / \mathrm{min}$ ) to $90^{\circ} \mathrm{C}$ without holding time.

Following the heat treatment, samples were cooled down by being placed in a plastic bag and immersed immediately in ice/water at $0-1^{\circ} \mathrm{C}$ for $30 \mathrm{~min}$, and then stored in a refrigerator $\left(4^{\circ} \mathrm{C}\right)$ overnight $(12-$ $15 \mathrm{~h})$. The procedure of heating gels by ohmic heating was photographed and shown in Fig. 3 and Fig. 4. 


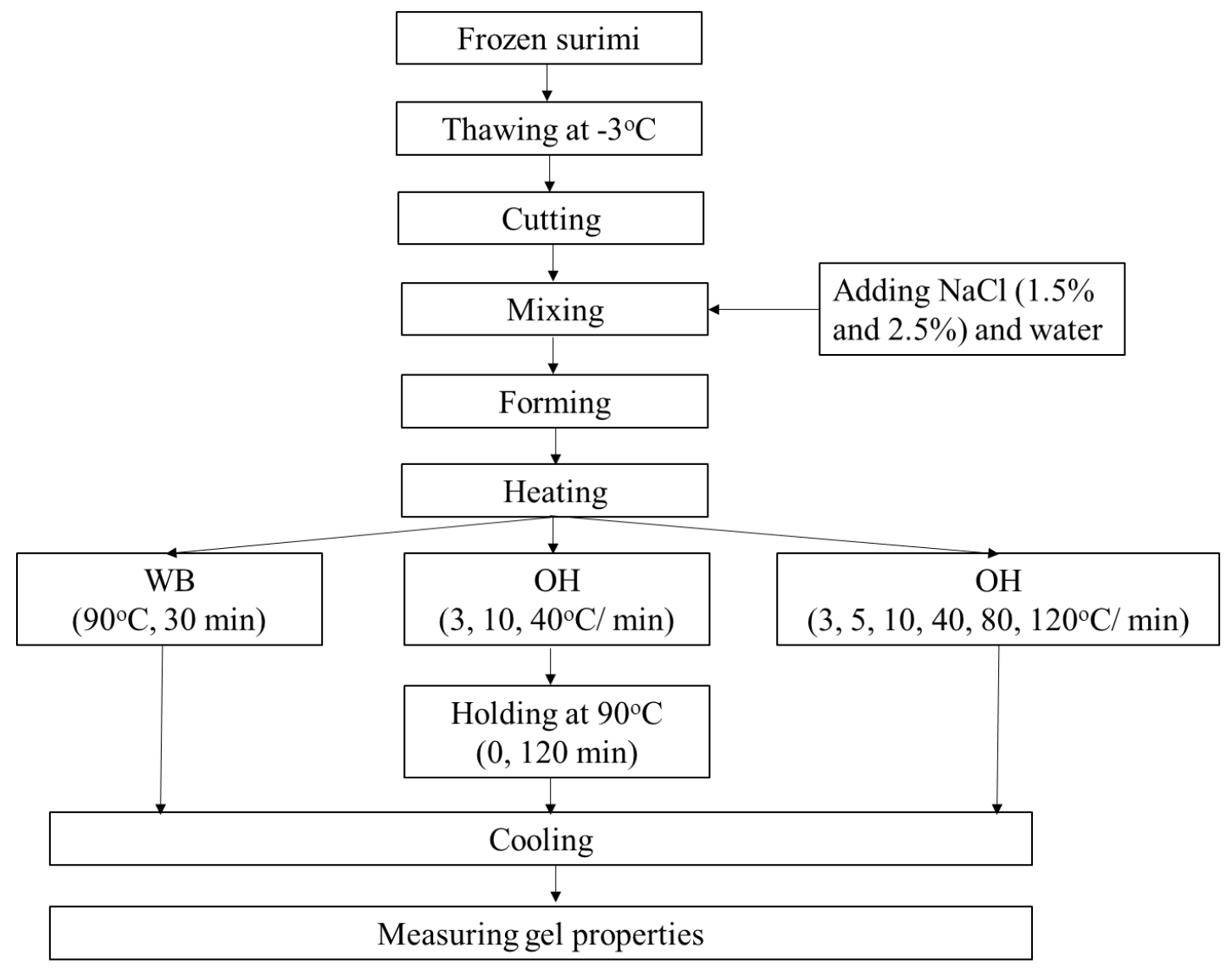

Fig. 2. Preparation of heat-induced surimi gel

(A) heating in a water bath to $90^{\circ} \mathrm{C}$ in 30min; (B) ohmic heating at 10,40 and $80^{\circ} \mathrm{C} / \mathrm{min}$ to $90^{\circ} \mathrm{C}$ for 0 and 120 sec;(C) ohmic heating at $3,5,10,40,80$, and $120^{\circ} \mathrm{C} / \mathrm{min}$ to $90^{\circ} \mathrm{C}$

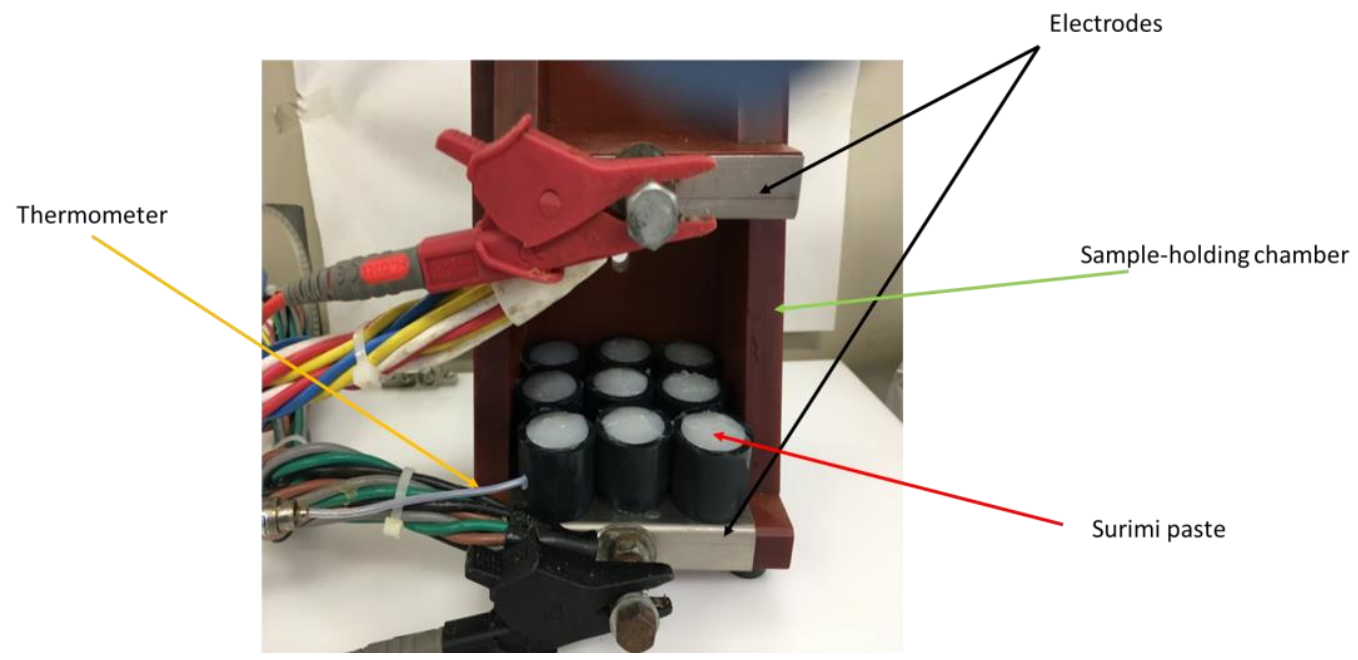

Fig. 3. A schematic diagram of the ohmic heating apparatus system 


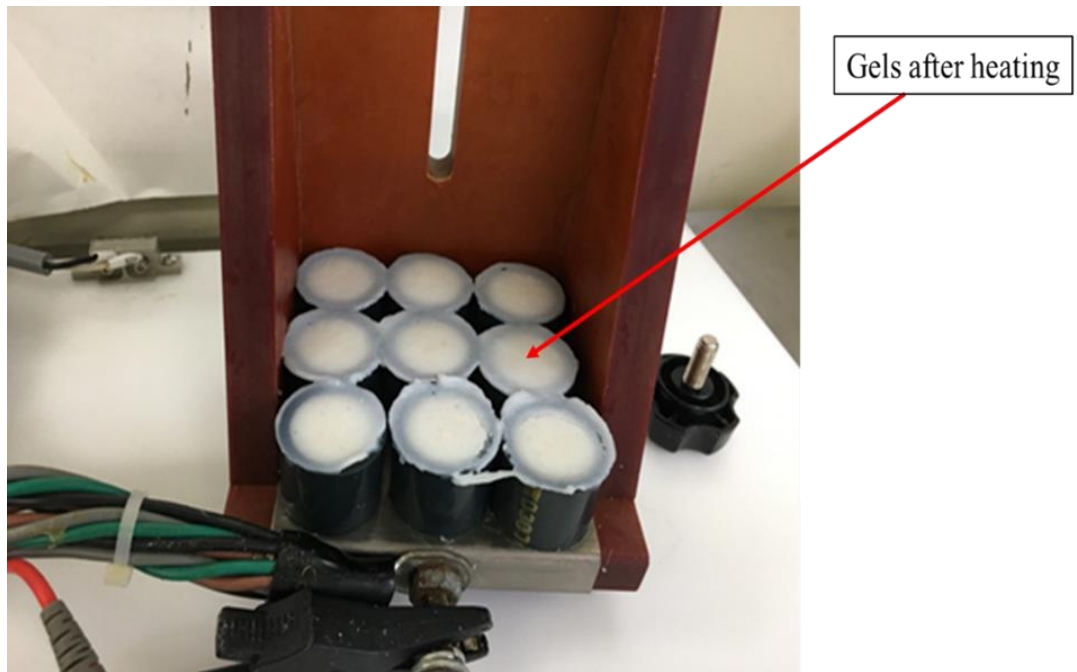

Fig. 4. Surimi gels prepared by ohmic heating

\subsection{Electrical conductivity measurement}

To measure the EC of the samples, surimi paste was stuffed into a polystyrene chamber between two titanium plate electrodes (width of $40 \mathrm{~mm}$, height of $50 \mathrm{~mm}$, and thickness of $0.05 \mathrm{~mm}$ ) that faced each other at the opposite ends of the chamber. The distance between the two electrodes was $30 \mathrm{~mm}$. A constant voltage of $50 \mathrm{~V}$ was applied to the electrodes until the designated temperature was reached. The instantaneous $Z, C, R_{p}$, and $R_{\mathrm{s}}$ values (Z: impedance, $\mathrm{C}$ : capacitance, $\mathrm{R}_{\mathrm{p}}$ : resistance paralell mode, $R_{\mathrm{s}}$ : resistance serries mode) of the samples were measured, as suggested by Liu et al. (2007), by using the LCR meter (Hi TESTER3532-50, HIOKI Co. Ltd., Japan) at one time point, at which the temperature of surimi paste reached $5^{\circ} \mathrm{C}$, and frequency was set at $20 \mathrm{kHz}$. All experiments were repeated three times. The EC, $\delta\left(\mathrm{S} \mathrm{m}^{-1}\right)$, was estimated from the geometry of the electrodes and the resistance by the following equation:

$$
\delta=\frac{1}{R} \times \frac{L}{A}
$$

Where $R$ is the electrical resistance of the food $(\Omega), L$ is the gap between the two electrodes (m), and $A$ is the surface area of the electrodes $\left(\mathrm{m}^{2)}\right.$ in contact with the surimi paste.

\subsection{Puncture test}

In order to evaluate deformability, breaking strength $(\mathrm{g})$ and breaking deformation $(\mathrm{mm})$ were determined using a texture analyzer (RE-3350B, Yamaden Ltd., Tokyo, Japan) according to the method described by Benjakul \& Visessanguan (2003), with

modifications. Six cylindrical-shaped samples (2.5 $\mathrm{cm}$ long) were prepared by keeping at room temperature $\left(25^{\circ} \mathrm{C}\right)$ for $1 \mathrm{~h}$ prior to analysis. A spherical probe (diameter $5 \mathrm{~mm}$ ) was used to penetrate the center of the gel sample perpendicularly at a constant crosshead speed $(60 \mathrm{~mm} / \mathrm{min})$ until the sample was punctured. The force to puncture the gel was recorded as breaking strength, and the distance from the point where the probe touched the gel to the point where the gel was punctured was recorded as breaking deformation $(\mathrm{mm})$.

\subsection{Expressible moisture measurement}

Expressible moisture was measured according to the method described by Rawdkuen et al. (2004), with modifications. Gel samples were cut into thin slices $(1.000 \pm 0.025 \mathrm{~g})(\mathrm{W} 1)$ and placed between 4 layers of filter paper (No. 4A paper on the inner side and No. 2 paper on the outer side). The filter papers were purchased from Advantec, Inc., Tokyo, Japan. Samples were then placed between 2 plastic plates (diameter: $4 \mathrm{~cm})$ and a constant force $\left(10 \mathrm{~kg} / \mathrm{cm}^{2}\right)$ was applied on top of the samples for $20 \mathrm{~s}$ using a rheometer (RE-3305, Yamaden Ltd., Tokyo, Japan) with 2 plastic plates attached to the crosshead (top) and the metal plate (bottom), following which the sample was weighed again (W2). Expressible drip content was calculated using the following equation and expressed as a percentage of sample weight:

$$
\text { Expressible drip }(\%)=\left[\left(\frac{(W 1-W 2)}{W 1}\right)\right] \times 100
$$




\subsection{SDS- PAGE}

To investigate the changes of protein pattern in surimi gels heated either, via a WB or OH, SDS-PAGE experiments were conducted according to the method described by Laemmli (1970). Samples for electrophoresis were prepared according to Kamath et al. (1992). The surimi gel (0.5 g) was cut and placed in $20 \mathrm{~mL}$ of buffer solution ( $\mathrm{pH} 8.0$ ) containing $2 \% \mathrm{SDS}, 8 \mathrm{M}$ urea, $20 \mathrm{~mL}$ Tris- $\mathrm{HCl}$, and $2 \%$ (v/v) $\beta$-mercaptoethanol ( $\mathrm{pH} 8.8)$, namely SDS-solution. The samples were boiled at $100^{\circ} \mathrm{C}$ and shaken continuously at room temperature for $24 \mathrm{~h}$ to solubilize the gel. The homogenized solutions were centrifuged at 10,000 $\times g$ (Sorvall, DuPont Co., Newton, CT, USA) for $10 \mathrm{~min}$ at room temperature. The protein concentration of supernatants was measured using Lowry's method (Waterborg, 2009) with bovine serum albumin as a standard. The SDS-solubility was then calculated by the protein concentration ratio in the SDS-solution before and after centrifugation. Samples (12 $\mu$ g protein) were loaded onto polyacrylamide gels comprised of a $7.5 \%$ stacking gel and 10\% running gel (e-PAGEL, Atto Co., Ltd., Tokyo, Japan) and subjected to electrophoresis using PAGE equipment (Atto Co., Ltd., Tokyo, Japan) at a constant current of $20 \mathrm{~mA}$. Polyacrylamide gels were stained with $0.05 \%$ Coomassie Brilliant Blue R-250 and de-stained with $30 \%$ methanol/10\% acetic acid $/ 60 \%$ water (v/v). Gel images were acquired using an Atto SDS-PAGE analysis system.

The quantitative analysis of MHC as relative staining intensity to actin (MHC/Ac) from the results of SDS-PAGE was conducted by analyzing the one-dimensional electrophoretic gels using the ImageJ software (NIH, Bethesda, MD, USA).

\subsection{Statistical analysis}

For each measurement, 6 samples were used to obtain the mean and standard deviation of breaking strength and distance. Next, 4-5 samples were used to obtain the mean and standard deviation of expressible moisture. Data were subjected to one-way analysis of variance using MS-Excel 2010 (Microsoft, Redmond, WA, USA). Differences between the samples were compared statistically using Tukey's method at a significant level of $p<0.05$.

\section{RESULTS AND DISCUSSION}

\subsection{Electrical conductivity of surimi paste}

Ohmic heating works effectively for foods because most foodstuffs contain dissolved ionic salts and acids, and water over $30 \%$, which render the material electrically conductive (de Alwis \& Fryer, 1992). The electrical conductivity of surimi paste added $1.5 \%$ and $2.5 \% \mathrm{NaCl}$ was depicted in Table 1 . The results indicated that higher electrical conductivity was associated with a high level of salt content. As salt content increased, the ions ( $\mathrm{Na}+$ and $\mathrm{Cl}-$ ) for con ducting electrical current increased, which increased conductivity. This linearly increasing trend agreed with results of Fryer et al. (1993) and Palaniappan \&Sastry (1991). Ionic constituents were important in conducting electrical currents through the surimi paste and other food materials during ohmic heating. According to Shiba (1992), impedance of surimi paste linearly decreased as it was heated ohmically from $5^{\circ} \mathrm{C}$ to $50^{\circ} \mathrm{C}$, indicating an increase of electrical conductivity with increased temperatures. For proper design of the ohmic heating system, it is essential to measure and collect the electrical conductivity data of foods as well as how they influence parameters such as frequency of the AC voltage applied, the voltage gradient, and the composition of food matrix. Some data has been published for highfrequency processes (e.g., microwave), but they are not applicable to low-frequency Ohmic heating processes. Only a few publications (Fryer et al., 1993; Salengke \& Sastry, 2007; Tulsiyan et al, 2008) have reported electrical conductivities of real food matrices as a mixture of both liquid and solid components. It is generally observed that the electrical conductivity of liquids is higher than that of solids (Sastry \& Palaniappan, 1992). In liquid foods, the effect of the proportion of solids is of less importance but still significant. Usually, as the percentage of solids increases (except for salt), the electrical conductivity decreases.

Table 1. Electrical conductivity of surimi paste (measured at $5^{\circ} \mathrm{C}$ )

\begin{tabular}{lrr}
\hline \% NaCl & $\mathbf{1 . 5}$ & $\mathbf{2 . 5}$ \\
\hline $\mathrm{Z}(\Omega)$ & $12.394 \pm 0.01228^{\mathrm{a}}$ & $8.3623 \pm 0.0506^{\mathrm{b}}$ \\
$\mathrm{L}(\mathrm{m})$ & 0.03 & 0.03 \\
$\mathrm{~A}\left(\mathrm{~m}^{2}\right)$ & 0.00188 & 0.00188 \\
$\mathrm{EC}(\mathrm{s} / \mathrm{m})$ & $1.2876 \pm 0.00127^{\mathrm{x}}$ & $1.908 \pm 0.0117^{\mathrm{y}}$ \\
\hline
\end{tabular}

$\mathrm{R}$ : electrical resistance $(\Omega)$,

L: gap between the two electrodes $(m)$,

A: surface area of the electrodes $\left(\mathrm{m}^{2}\right)$,

EC: electrical conductivity $(\mathrm{s} / \mathrm{m})$

\subsection{Textural properties}

Breaking force and deformation of croaker surimi gels with addition of $1.5 \% \mathrm{NaCl}$ or $2.5 \% \mathrm{NaCl}$ thermally treated by water-bath or ohmic heating, are shown in Fig 5 (a) and (b); Fig 6 (A) and (B), 
respectively. Compared with the conventional water-bath heating, the appropriate ohmic heating (heated at slow heating rates: $3^{\circ} \mathrm{C} / \mathrm{min}, 5^{\circ} \mathrm{C} / \mathrm{min}$, and $10^{\circ} \mathrm{C} / \mathrm{min}$ ) improved the mechanical and functional properties of the gels prepared from croaker surimi, including low-salt gel and regular-salt gel.

In this study, the effect of holding time (the time that holds samples at the final temperature) was also investigated because it was unclear whether the shorttime heating by ohmic heating was enough or not for the complete gelation of surimi protein. The results obtained were impressive: the mechanical and functional properties seemed to remain stable as the heating time was prolonged for $120 \mathrm{sec}$ when the temperature reached $90^{\circ} \mathrm{C}$ in both slow and fast heating speed. This is probably since all fish proteins are completely cooked when the internal temperature exceeds $75^{\circ} \mathrm{C}$ (Thawornchinsombut \& Park, 2007).

SA grade croaker surimi is considered high-grade surimi, with very little or no enzymatic degradation, supported by the similarity in gel force and distance values for $\mathrm{WB}$ and $\mathrm{OH}$ at fast heating rates $\left(80^{\circ} \mathrm{C} / \mathrm{min}\right.$ and $\left.120^{\circ} \mathrm{C} / \mathrm{min}\right)$ regardless of the salt concentration. Statistical analysis showed no significant difference between the results obtained fromconventional and fast ohmic cooking for croaker surimi (Fig 6), indicating that there is little presence of proteolytic enzymes in this high-grade surimi (Reppond \& Babbitt, 1993). These results are different from the results obtained by Park \& Yongsawatdigul (1999) with Pacific whiting surimi, which is loaded with a high level of proteolytic enzymes, demonstrated better gelation properties as the heating rate increased.

As shown in Table 2, in order to achieve the same heating time to reach $90^{\circ} \mathrm{C}$ for the samples with two different salt concentrations, the applied voltage gradient had to be adjusted. The lower-salt paste required a higher voltage gradient due to its lower electrical conductivity. Whereas, the higher-salt paste required a lower voltage gradient due to its higher electrical conductivity. Therefore, the difference in breaking strength and deformation between low and high-salt gel mainly due to the solubility of the protein itself. Fig 5 (a), (b) and Fig 6 (A), (B) showed that breaking strength and deformation of gels added $2.5 \% \mathrm{NaCl}$ were higher than those values of gels added $1.5 \% \mathrm{NaCl}$. It is well known that protein solubilization of myofibrillar proteins in salt solutions is related to functional properties of fish meat such as gel-forming ability, emulsifying property, and water-holding ability (Suzuki, 1981). Hence, these results are in agreement with the previous studies related to the effect of salt content in heat-induced gels.

The ohmic heating has become a new method for muscle product heating due to its various advantages like rapid heating, high efficiency, sound control, and sanitation. According to Marcotte et al. (2010), compared with the water-bath heating, the surimi samples absorbed the same or less energy during ohmic heating, while the breaking force of the gel was increased mainly; thus, the ohmic heating showed more advantages, which was consistent with the results of the present study. Similarly, Huang et al. (1997) successfully investigated the feasibility of using a batch-type ohmic heater to coagulate fish proteins from the frozen fish mince wash water. Ohmic heating was employed as a rapid method of heating and was found to maximize gel functionality in Pacific whiting surimi as compared to conventional heat treatment, which allows the product to develop undesirable textural properties as a result of optimal enzymatic activity occurring at $55^{\circ} \mathrm{C}$ (Yongsawatdigul et al. 1995). 

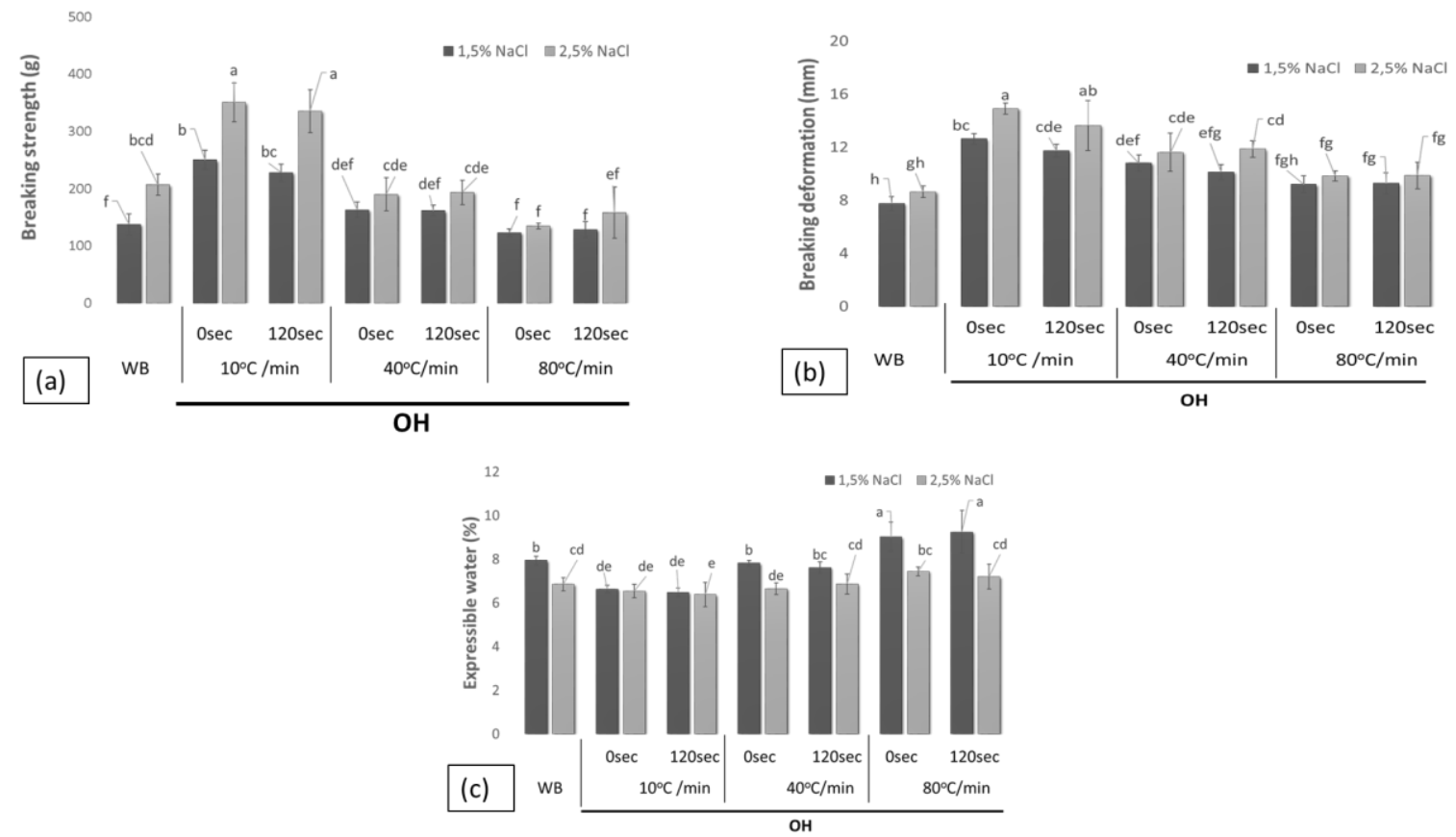

Fig. 5. Breaking strength (a), breaking deformation (b), and WHC (c) of croaker surimi gels heated by $\mathrm{WB}$ and $\mathrm{OH}$ at different heating rates and holding time

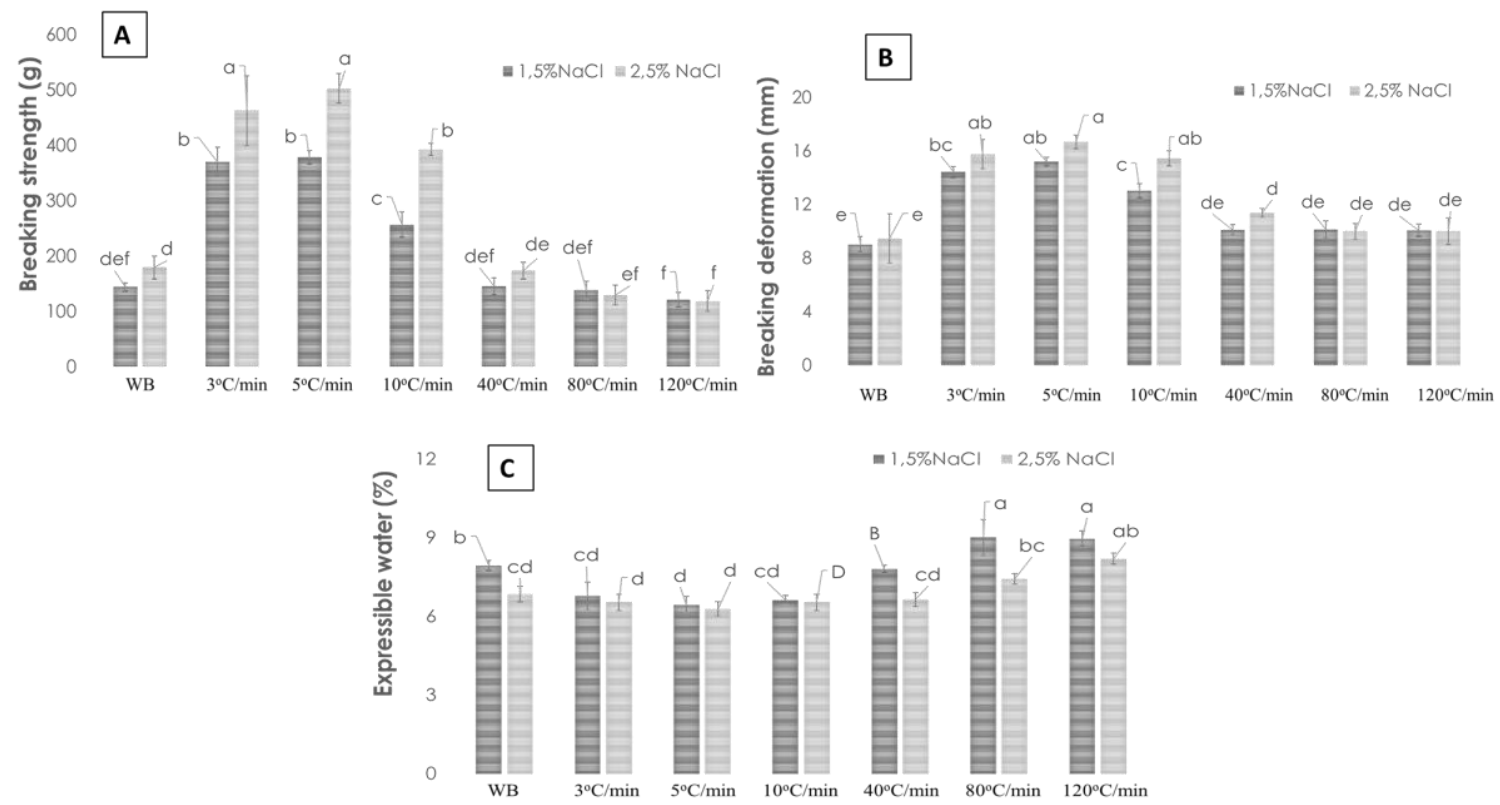

Fig. 6. Breaking strength (A), breaking deformation (B), and WHC (C) of croaker surimi gels heated by $\mathrm{WB}$ and $\mathrm{OH}$ at different heating rates without holding time 
Table 2. Heating conditions of heat-induced surimi gels

\begin{tabular}{|c|c|c|c|c|c|c|}
\hline \multirow{2}{*}{ Heating rate } & \multicolumn{2}{|c|}{$\begin{array}{c}\text { Voltage gradients } \\
\text { (V/cm) }\end{array}$} & \multirow{2}{*}{$\begin{array}{r}\text { Heating time } \\
(\mathrm{s})\end{array}$} & \multirow{2}{*}{$\begin{array}{r}\text { Holding time } \\
\text { (s) }\end{array}$} & \multirow{2}{*}{$\begin{array}{r}\text { Initial tempera- } \\
\text { ture } \\
\left({ }^{\circ} \mathrm{C}\right)\end{array}$} & \multirow{2}{*}{$\begin{array}{r}\text { Target tem- } \\
\text { perature } \\
\left({ }^{\circ} \mathrm{C}\right) \\
\end{array}$} \\
\hline & $\begin{array}{l}1.5 \% \\
\mathrm{NaCl} \\
\end{array}$ & $\begin{array}{l}2.5 \% \\
\mathrm{NaCl} \\
\end{array}$ & & & & \\
\hline $3^{\circ} \mathrm{C} / \mathrm{min}$ & 4.6 & 3.8 & 1800 & 0 & 0 & 90 \\
\hline $5^{\circ} \mathrm{C} / \mathrm{min}$ & 5.4 & 4.4 & 1080 & 0 & 0 & 90 \\
\hline $10^{\circ} \mathrm{C} / \mathrm{min}$ & 6.8 & 5.72 & 540 & 0,120 & 0 & 90 \\
\hline $40^{\circ} \mathrm{C} / \mathrm{min}$ & 12.0 & 10.0 & 145 & 0,120 & 0 & 90 \\
\hline $80^{\circ} \mathrm{C} / \mathrm{min}$ & 18.4 & 14.0 & 70 & 0,120 & 0 & 90 \\
\hline $120^{\circ} \mathrm{C} / \mathrm{min}$ & 22.0 & 18.0 & 45 & 0 & 0 & 90 \\
\hline Water bath & & & 1800 & 0 & 0 & 90 \\
\hline
\end{tabular}

\subsection{Water holding capacity (WHC)}

WHC of gels varied with salt concentrations and heating treatments ( $p<0.05$, Fig 5 c, Fig 6 C). Surimi gel cooked ohmically, with the addition of $2.5 \% \mathrm{NaCl}$, exhibited the highest WHC $(P<0.05)$. Gels cooked by ohmic heating at slow heating rate $\left(3^{\circ} / \mathrm{min}, 5^{\circ} \mathrm{C} / \mathrm{min}\right.$, and $\left.10^{\circ} \mathrm{C} / \mathrm{min}\right)$ showed higher WHC than water bath-cooked gels $(P<0.05)$. WHC correlated well with breaking force and deformation of surimi gels (Fig $5 \mathrm{a}$, b; Fig $6 \mathrm{a}, \mathrm{b}$ ). The holding time at $90^{\circ} \mathrm{C}$ also showed no effect on WHC of heatinduced gels. Our findings agree with the data reported by Shirsat et al. (2004), who reported that WHC of steam-cooked emulsified meat batter was significantly lower than those of samples cooked ohmically at 3,5 , or $7 \mathrm{~V} / \mathrm{cm}$. An increase in WHC was also found in a large diameter comminuted meat product cooked by a rapid heating method of radiofrequency (Zhang et al., 2004). These results confirmed that the gel network might not be fully developed to entrap water molecules under a rapid heating regime. Therefore, proper heating rate to induce unfolding of myofibrillar in croaker surimi would be under slow ohmic heating.

\subsection{SDS- PAGE}

The results about protein patterns were shown in Fig 7. On SDS-PAGE gels (Fig 7), croaker surimi proteins produced two bands, of which the most abundant proteins were myosin heavy chains (MHC, 205 $\mathrm{kDa})$ and actin $(45 \mathrm{kDa})$. Ohmic heating at slow heating rate $\left(3^{\circ} / \mathrm{min}, 5^{\circ} \mathrm{C} / \mathrm{min}\right)$ significantly decreased the content of MHC (lane 3, 5) compared with that of surimi gels under other treatments in both salt concentrations The phenomenon of decreasing MHC was more apparent in gels with higher salt content (Fig. 7A, 7B). Compared the band intensity in the top of lanes, which were higher in lanes 3 and 5, a larger molecule weight band (higher than MHC) was formed in the gels induced by the slow heating rate (Fig 7). These results suggest that the formation of cross-linking stabilized by covalent bonds, which helps to improve the gel strength (Rawdkuen et al., 2004). The endogenesis TGase was suggested to contribute the cross-linking of protein under setting conditions $\left(40^{\circ} \mathrm{C}\right)$, leading to enhanced strength of surimi gels (Benjakul et al., 2004). However, in the present study, the water bath heating and ohmic heating at $3^{\circ} \mathrm{C} / \mathrm{min}$ were set under the same heating time $\left(30 \mathrm{~min}\right.$ to $90^{\circ} \mathrm{C}$; Table 2$)$, but the results in protein pattern were different; relatively reduced staining intensity of MHC was observed in slow $\mathrm{OH}$ heated gels compared with WB heated gels (Fig. 7 A, B). The low staining intensity of MHC/Ac in Fig. $7 \mathrm{C}$ also confirmed this tendency of the slow heated gel. Furthermore, it was confirmed that the staining intensity of $\mathrm{MHC} / \mathrm{Ac}$ showed a decreasing tendency as the heating rate decreased, and this tendency was almost similar to the change in breaking strength of $\mathrm{OH}$ gels with different heating rates (Fig. 5, 6). Thus, the difference in protein cross-linking may mostly be due to the difference in the effect of heating method (Nguyen et al., 2020). 
$1,5 \% \mathrm{NaCl}$

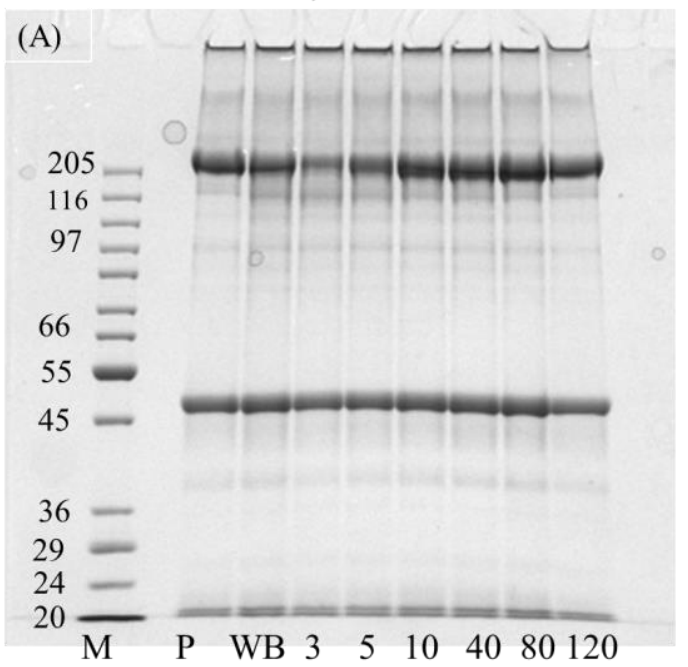

$2,5 \% \mathrm{NaCl}$

(B)

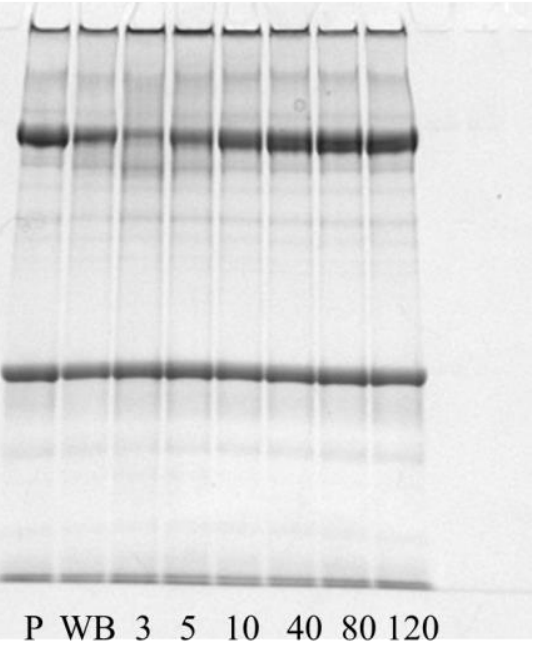

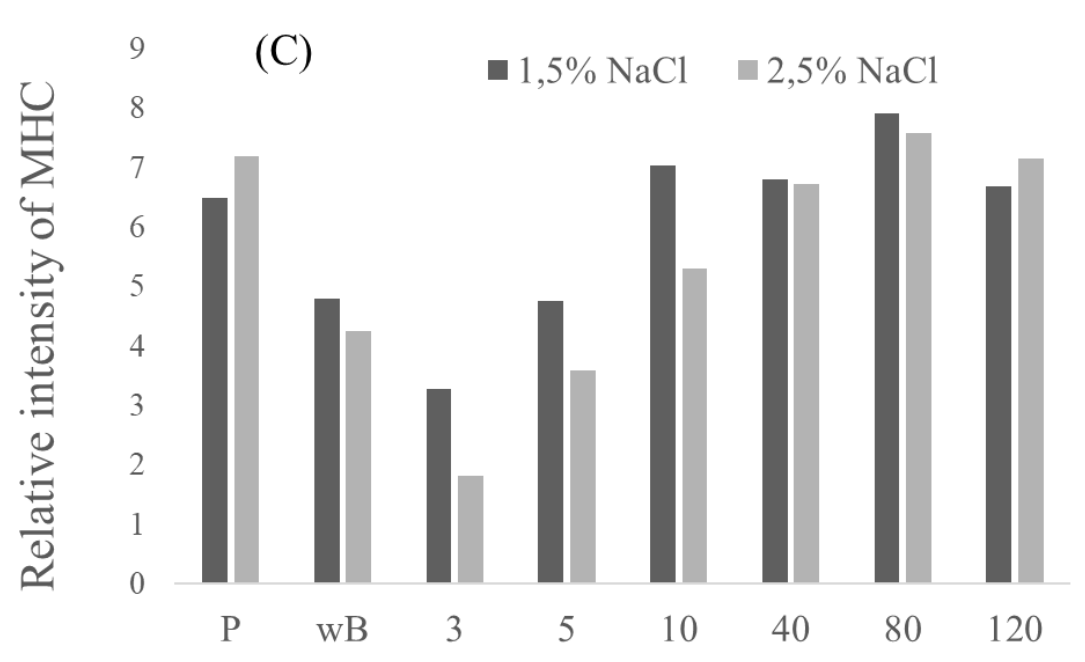

Fig. 7. SDS-PAGE pattern of croaker surimi gels prepared with $1.5 \% \mathrm{NaCl}(\mathrm{A})$ and $2.5 \% \mathrm{NaCl}(\mathrm{B})$ affected by heating methods

$M=$ molecular weight marker, $M H C=$ myosin heavy chain, $P=$ surimi paste, $W B=$ water bath heating; 3, 5,10, 40, 80, $120(\mathrm{oC} / \mathrm{min})=\mathrm{OH} .(\mathrm{C})$ The band intensities were quantified by software ImageJ. The relative MHC intensity (MHC R.I.) showed in the bar graph.

\section{CONCLUSIONS}

Ohmic heating can be employed as an alternative heating method for heating surimi-based product as it significantly impoved the gelation of surimi gel. At the same heating rates, higher salt concentration $(2.5 \% \mathrm{NaCl})$ generated better surimi gels for croaker surimi. Gels cooked ohmically at slow heating rate performed significantly better than those cooked conventionally in a water bath. There was little discernible difference in protein pattern between gels heated by $\mathrm{OH}$ and conventional WB heating at fast heating rates with two different salt concentrations. At a very slow heating rate $\left(3^{\circ} \mathrm{C} / \mathrm{min}\right.$ and $\left.5^{\circ} \mathrm{C} / \mathrm{min}\right)$, showed a significant difference in protein pattern between gels heated by $\mathrm{OH}$ and conventional WB heating with two different salt concentrations.

\section{REFERENCES}

Benjakul, S. \& Visessanguan, W. (2003). Transglutaminase mediated setting in bigeye snapper surimi. Food Research International, 36(3), 253-266. 
Benjakul, S., Visessanguan, W., \& Pecharat, S. (2004). Suwari gel properties as affected by transglutaminase activator and inhibitors. Food Chemistry, 85(1), 91-99.

de Alwis, A. A. P., Halden, K., \& Fryer, P. J. (1990). Shape and conductivity effects in the ohmic heating of foods. Chemical Engineering Research and Design, 67(2), 159-68.

de Alwis, A.A.P. \& Fryer, P.J. (1992). Operability of the Ohmic heating process: Electrical conductivity effects. Journal of Food Engineering, 15(1), 21-48.

Fryer, P. J., De Alwis, A. A. P., Koury, E., Stapley, A. G. F., \& Zhang, L. (1993). Ohmic processing of solidliquid mixtures: heat generation and convection effects. Journal of Food Engineering, 18(2), 101-125.

Huang, L., Chen, Y., \& Morissey, M. T. (1997). Coagulation of fish proteins from frozen fish mince wash water by ohmic heating. Journal of Food Process Engineering, 20(4), 285-300.

Kamath, G., Lanier, T., Foegeding, E., \& Hamann, D. (1992). Nondisulfide covalent cross-linking of myosin heavy chain in "setting" of Alaska pollock and Atlantic croaker surimi. Journal of Food Biochemistry, 16(3), 151-172.

Laemmli, U. K. (1970). Cleavage of structural proteins during the assembly of the head of bacteriophage T4. Nature, 227(5259), 680.

Liu, R., Zhao, S., Xiong, S. B., Xie, B. J. \& Liu, H. M. (2007). Studies on fish and pork paste gelation by dynamic rheology and circular dichroism. Journal of Food Science, 72(7), 399-403.

Marcotte, M., Ramaswamy, H. S., Karimi-Zindashty, Y., \& Zareifard, M. R. (2010). Ohmic heating effects on rheological and functional properties of foods. Novel Food Processing. Effects on Rheological and Functional Properties, 21-34.

Nguyen, V. T., Park, J. W., Liqiong, N., Nakazawa, N., Osako, K., \& Okazaki, E. (2020). Textural Properties of Heat-induced Gels Prepared Using Different Grades of Alaska Pollock Surimi under Ohmic Heating. Food Science and Technology Research, 26(2), 205-214.

Palaniappan, S., \& Sastry, S. K. (1991). Electrical conductivities of selected solid foods during ohmic heating 1. Journal of Food Process Engineering, 14(3), 221-236.

Park, J.W. \& Yongsawatdigul, J. (1999). Gelation properties of fish proteins under Ohmic heating. In: Quality Attributes of Muscle Foods, eds. Y. Xiong, F. Shahidi, and C.-T. Ho (pp. 421-429). New York, NY: Plenum Press.

Rawdkuen, S., Benjakul, S., Visessanguan, W. \& Lanier, T. C. (2004). Chicken plasma protein affects gelation of surimi from bigeye snapper. Food Hydrocolloids, 18(2), 259-270.

Reppond, K. D., \& Babbitt, J. K. (1993). Protease inhibitors affect physical properties of arrowtooth flounder and walleye pollock surimi. Journal of Food Science, 58(1), 96-98.

Resources Council, Science \& Technology Agency, Japan (2000). Standard tables of food composition in Japan. Resources Council Report, 87, 41-42.

Salengke, S., \& Sastry, S. K. (2007). Experimental investigation of ohmic heating of solid-liquid mixtures under worst-case heating scenarios. Journal of food Engineering, 83(3), 324-336.

Sastry, S. K., \& Palaniappan, S. (1992). Mathematical modeling and experimental studies on ohmic heating of liquid-particle mixtures in a static heater. Journal of Food Process Engineering, 15(4), 241-261.

Shiba, M. (1992). Quality of heated gel from walleye pollack surimi by applying joule heat. Nippon Suisan Gakkaishi, 58(5), 903-907.

Shirsat, N., Brunton, N. P., Lyng, J. G., McKenna, B., \& Scannell, A. (2004). Texture, colour and sensory evaluation of a conventionally and ohmically cooked meat emulsion batter. Journal of the Science of Food and Agriculture, 84(14), 1861-1870.

Suzuki, T. (1981). What is frozen minced meat (surimi). In T. Suzuki (Ed.), Fish and krill protein. Processing technology (pp. 133-134). London: Applied Science.), Publishers Ltd.

Thawornchinsombut, S. \& Park, J.W. (2007). Effect of $\mathrm{NaCl}$ on gelation characteristics of acid- and alklitreated Pacific whiting fish protein isolates. Journal of Food Biochemistry, 31(4), 427-455.

Tuankriangkrai, S., \& Benjakul, S. (2010). Effect of modified tapioca starch on the stability of fish mince gels subjected to multiple freeze-thawing. Journal of Muscle Foods, 21(3), 399-416.

Tulsiyan, P., Sarang, S., \& Sastry, S. K. (2008). Electrical conductivity of multicomponent systems during ohmic heating. International Journal of Food Properties, 11(1), 233-241.

Varghese, K. S., Pandey, M. C., Radhakrishna, K., \& Bawa, A. S. (2014). Technology, applications and modelling of ohmic heating: a review. Journal of Food Science and Technology, 51(10), 2304-2317.

Vicente, A. A., Castro, I., \& Teixeira, J. A. (2006). Innovations in thermal food processes. In Da-Wen Sun (Ed.), Thermal food processing: New technologies and quality issues (pp. 424-468). Boca Raton, FL, USA: CRC Press, Taylor \& Francis Group

Waterborg, J. H., \& Matthews, H. R. (1994). The Lowry method for protein quantitation. Basic protein and peptide protocols, 1-4. Yongsawatdigul, J., Park, J. W., \&Kolbe, E. (1995). Electrical conductivity of Pacific whiting surimi paste during ohmic heating. Journal of Food Science, 60(5), 922-925.

Zhang, L., Lyng, J. G., \& Brunton, N. P. (2004). Effect of radio frequency cooking on the texture, colour and sensory properties of a large diameter comminuted meat product. Meat science, 68(2), 257-268. 